\title{
DEFINING THE GENRE OF MEXICAN BUSINESS E-MAIL
}

\section{Therese Judge*}

Abstract: Based on congruencies in the findings of Spanish-language writing research and U.S.-English e-mail writing research, this study investigates Mexican e-mails. The findings from the literature are formulated as issue statements for the purpose of confirming or denying their applicability to collected Mexican e-mails. The study employs both qualitative rhetorical analysis and a quantitative feature presence/absence analysis. Of the eight issues statements predicted to describe Mexican business e-mails per the literature, only one was affirmed-meaning that the currently available information about Mexican workplace e-mails is incorrect and/or incomplete.

Keywords: Genre. Intercultural. E-mail. Spanish.

\section{VALUE OF STUDIES OF} NON-ENGLISH WRITING GENRES IN THE U.S.

Genre studies may serve both practical and theoretical purposes. The primary purpose of the present research is practical. The results are intended for application in areas such as augmenting relevant information for teaching intercultural written communication. Secondarily, data from this study may be useful to researchers developing general theories of writing. This section begins with the primary motivators and finishes with the secondary.

\subsection{Intercultural communication weaknesses}

In the U.S., the teaching practices for "foreign languages" (languages other than English-LOTEs) differ markedly from the teaching practices for English as a Second Language (ESL). Practitioners in the field of ESL have researched and documented many writing genres, perhaps most famously Swales' study of research reporting

\footnotetext{
* Grand View University; Associate Professor of English and Chair of the English Department; Doctor of Philosophy; Rhetoric and Professional Communication. Email: tjudge@grandview.edu.
} 
(SWALES, 1990). Practitioners in the foreign language field have not pursued this type of research into writing genres. In general, foreign language instruction remains tied to the study of the language's literature with writing focused on the genres of the academy (REICHELT, 2001; VALDES; HARO; ECHEVARRIARZA, 1992; CIBER.) Graduates who hope to use their new language skills in their business careers, often lack background in how to write for the world of business. Experts in intercultural communication point to this lack of writing skill as a major roadblock to these students' professional success.

Ulla Connor attributes non-natives' lack of success in second language writing largely to their lack of familiarity with the genre expectations of target cultures (Connor cited in MARTIN, 2003, p. 26). Because "the logical development of texts is not universal but language/culture specific, it is imperative that language teachers be aware of differences in discourse features and teach these to students developing literacy skills in a second language (MONTAÑO-HARMON, 1991, p. 425). Montaño-Harmon brings specificity to Connor's claim stating that without instruction that provides second language learners with the written genre expectations of the target language readers, they risk offending their readers.

English-speaking writers [who] compose texts in Spanish using the deductive, linear discourse pattern of English, at best [...] will sound simplistic and juvenile, or boring and dry to a native speaker of Spanish. At worst, the writer will project a hidden message of abruptness, even rudeness, insulting his Spanish-speaking reader with a linear, deductive, enumerative composition. (MONTAÑO-HARMON, 1991, p. 424)

In addition to students of "foreign languages," students from other disciplines also lack specific materials to guide writing effectively for intercultural business. For example, authors of textbooks for students who anticipate writing to be an important part of their careers, such as technical writers and business majors, discuss the fact that rhetoric differs by culture (e.g., ANDERSON, 2007; BURNETT, 2006; LANNON, 2003). What they do not and can not do, however, is provide guidelines for each possible LOTE. That type of writing instruction is beyond the scope of those textbooks. 
What is needed is research to describe the particulars of workplace genres of LOTE cultures. Regarding Spanish in the Americas, TEBEAUX (1999, p. 71) and MAURIAL (1995, p. 142), report that Latino cultures do not address business writing genres in higher education and thus, the information is not yet available from our research colleagues in in these countries. To prepare students for the intercultural business community, we need to define the characteristics of common business writing genres. To encourage this type of research, perhaps a sister journal to English for Specific Purposes such as "LOTEs for Specific Purposes" would be appropriate. Such a research emphasis could also alleviate some of the concern for the ethnocentric focus of much of current writing studies.

\subsection{A general theory of writing}

The primary purpose of this research is not to contribute to a general theory of writing, but from a theoretical standpoint, studying various languages written for various purposes while building a theory of writing is much more appropriate than focusing on one language alone. Reichelt (REICHELT, 1999) quotes Silva on the bias in writing studies research saying we could do much to enhance and legitimize current mainstream (L1 based) theories of writing by making them less narrow: less monolingual, less monocultural, less ethnocentric, less fixated on writing by eighteen-year-old native speakers of English in North American colleges and universities and more inclusive, more realistic, more generalizable, and ultimately, more valid (p. 182).

Even though the Journal of Second Language Writing openly encourages submission of studies of LOTEs, REICHELT (1999, p. 181) found that between 1992 and 1999 only three out of eighty-one articles published dealt with LOTEs. The research field is wide open.

\subsection{Spanish language writing studies}

Two broad categories of Spanish writing studies are found in the scholarly journals in the U.S. Researchers have focused on academic writing genres and professional writing genres. For this report, academic writing genres are those written by students to meet the requirements of 
an educational institution or instructor, such as term papers, research reports, theses and dissertations. Professional writing carried out by academics as part of their scholarly programs will be considered "professional" writing. This differs from the stance taken by Martín and Simpson, but concurs with that of Hyon and Rong (HYON, 2004).

\subsubsection{Academic writing genres}

Much of the research into Spanish academic writing has remained in the form of unpublished dissertations, e.g., SANTIAGO (1970), STREI (1972) and SANTANA-SEDA (1974) to name a few. This contrastive rhetoric research, cited in other published works, found that Spanish writing bore "striking differences in the organization" of compositions compared to U.S. English and could be described as exhibiting a "flowery or ornate style" (MONTANO-HARMON, 1991, p. 418). The Spanish compositions had "significantly higher proportions of coordinate structures, nonsequential sentences, additive constructions (additive coordination versus subordinate coordination typical of U.S. English), and one- and two-sentence paragraphs" (KAPLAN, 1976). Academic writing then, appears to favor these stylistic choices.

A 1998 study found that the academic writing of Spanish-speaking students has significantly longer sentences and significantly more pronouns and conjunctions (REID, 1988). Montaño-Harmon found that Mexican students' essays, compared to U.S. English students' essays, demonstrate a tendency toward run-on sentences, rely heavily on synonyms as a cohesive device, and deliberately break connections between one idea and the next and transition back to the original idea. (MONTAÑO-HARMON, 1991, p. 420-422). Another study noted a greater number of adjectival, adverbial and nominal clauses in Ecuadorian students' writing [Lux cited in REPPEN (1993, p. 117)]. Reppen and Grabe's study, among other findings confirmed the "ornate, flowery and formal" characteristics of Spanish influenced writing (1993, p. 127).

These academic writing studies influence perceptions about writing for Spanish speaking readers, particularly the "ornate, flowery and formal" descriptor. This vision of Spanish writing might be labeled the "common knowledge" view of people involved with teaching 
Spanish as a second language. Because academic writing can be ornate and flowery, among other characteristics, this fact has had an influence on researchers in studies of non-academic writing. More care and detail needs to be taken in describing the genre of writing under study. Saying that Spanish writing is ornate and flowery conflates characteristics of academic writing with all Spanish writing.

\subsubsection{Professional writing genres}

Ortiz studied the characteristics of professional writing done by five Mexican business owners situated along the Mexico/U.S. border at Ciudad Juárez/El Paso (ORTIZ, 2005). Importantly, she found direct and practical written communications combined with formal and conversational styles with some "residue of the legalistic, overly formal jargon from an older style of business writing" (p. 39). She also found some long sentences and complicated clause structures "typical of written Spanish in more formal registers" (p. 41).

Even though her article is titled, "Designing written business communication along the shifting cultural continuum: The new face of Mexico," Tebeaux's article contains only three pages (out of 36) that describe design considerations for Mexican business communication (TEBEAUX, 1999). Much of the rest of the article proposes an explanation for why the writing practices of U.S. business culture differs from that of the Mexican business culture. Nonetheless, she tells us that Mexican business letters delay stating the purpose of the letter (p. 56); use effusive, elegant, and opulent language (p. 57); lack a tone of certainty (p. 60); use a deferential tone appropriate to the rank, age and gender of the reader often sounding obsequious by U.S. standards (p. 61); exude elegance, dignity and sonorous expression (p. 61); demonstrate emphasis on relationships by using long, euphonious, evasive phrases designed to express respect, honor, affection and emotion more so than business transaction (p. 63); use a style that exudes dignity, strength, braggadocio, and posturing (p. 64).

In studies of documents and training practices in South America, Thatcher found that South American rhetorical choices favor oral modes of communication (THATCHER, 1998, p. 372); (THATCHER, 1999, p. 181) and accumulative or additive organization patterns. And, in addition 
to many of the findings of the academic writing studies above, Thatcher also writes that South American writing can generally be described as organizationally flexible with circumlocutory paragraph development, longer, more subordinated sentences, and more conscious deviations, digressions and run-on sentences (1998, p. 373). He also found much more detail in context setting and a propensity for a narrative prose style (1999, p. 177). One final point that Thatcher makes is the South Americans' preference for originality or creativity in writing. This style of writing leads to a heavy use of synonyms and perhaps more dynamic vocabulary, corroborating Montaño-Harmon's "flowery writing" descriptor (p. 423).

Joellen Simpson investigated the cohesive practices of academics' professional writing (SIMPSON, 2000). She compared paragraph cohesion in U.S. English language refereed journals with Latin American Spanish language refereed journals using Lautamatti's topical structure analysis (TSA) model. The model tracks sentence topics and plots them onto a graph representing their thematic development. In comparing the samples, Simpson found that the English writers repeat topics as a cohesive move more often than Spanish writers, $46 \%$ compared to $32 \%$; English employs slightly more parallel progressions, $17.7 \%$ versus $12.2 \%$; English favors a rheme/theme cohesive device, $16.8 \%$ versus $6.6 \%$. In fact, the rheme/theme constructions are valued as a sophisticated technique for lending coherence to a paragraph in U.S. English (p. 305).

In studying academic professional writing, Moreno investigated the ways in which authors of business and economics refereed articles present claims in premise-conclusion sequences (MORENO, 2004). Moreno's focus was on the metatext, or text that helps readers organize, interpret and evaluate the ideas presented; for example, author references to previously mentioned ideas as "these results," "the preceding subsection," "this means," and "these inconsistencies" (MORENO, 2004, p. 322). Moreno found that Spanish-language writers used generic labels such as "this" or "all this" nearly three times as often as the English-language writers. She also found that Spanish-language writers select visual nouns much more frequently than their English-speaking peers $(26.51 \%$ rate compared to $19.4 \%)$, employ precise referents at a rate of $39.66 \%$ compared to $0 \%$, and use many fewer class or category referents $(27.59 \%$ compared to $41.14 \%)$. 
Another genre study contrasts the sub-genre of abstracts in scholarly journals in Spanish and English. The study investigated abstracts in English for scholarly journals published for international audiences and in Spanish for Spanish journals (MARTIN, 2003). The researcher compares the presence of Swales' four research reporting moves in the abstracts of 160 articles, half of them in Spanish and half in English. The moves, introduction, methods, results, and conclusion appear in the majority of abstracts studied with the exception of the results section. Please see the following table for his results.

Table 1 - Presence of Swales' moves in refereed article abstracts, Spanish and English

\begin{tabular}{lrr}
\hline Element & English & Spanish \\
\hline Introduction & 98.75 & 100,00 \\
Methods & 82.50 & 81.25 \\
Results & 86.25 & 41.25 \\
Conclusion & 88.75 & 72.50 \\
\hline
\end{tabular}

Source: Martín (2003, p. 29)

In discussing his findings, Martín explains the following rhetorical differences between the two categories of article abstracts: 1. Englishlanguage abstracts had a much higher rate of justifying the research in their introductions (p. 32), 2. Spanish methods sections tend to be longer than the English methods sections (p. 36), 3. Spanish results sections favored active voice and present tense over the English passive voice and past tense (p. 37), 4. English-language abstracts were much more likely to hedge in the conclusion portion $(63.3 \%$ rate compared to $17.2 \%)($ p. 40).

\subsection{Comments on and summary of the Spanish language writing studies}

The reliability of some of the studies' results may be questionable because of the lack of identification of the variety of Spanish under study. In some cases researchers do clearly identify that subjects are from a given country, but it is much more common for researchers to simply label the subjects as Spanish or English speakers without information 
about the variety of the language they speak. Of course, labeling someone as a speaker of Mexican Spanish or U.S. English does not account for regional variations within those categories. However, identifying as clearly as possible the language under study would help future researchers and lend greater credibility to the generalizability of findings.

Another constraint on the studies' reliability is the wide variety of and often under-described methods. Without clearer information about how the data are collected or measured, we cannot gauge the significance of results. Further, nonspecific descriptions of writing practices such as "flowery and ornate" make it impossible to confirm or deny claims.

Summarizing the findings of these studies: 1. Thatcher's (1998, p. 327 and 1999, p. 177) and Martín's (p. 40) studies corroborate each others' findings related to specificity and detail. 2. Montaño-Harmon (p. 418), Tebeaux (p. 57), and Thatcher (1998, p. 373) describe Spanish writing as following a non-linear organization pattern. 3. Thatcher (1998, p. 327; 1999, p. 177) and Martín (p. 40) describe Spanish writing as containing large amounts of very highly specific detail and little hedging or generalization. 4. Thatcher, Tebeaux, Martín and Moreno all discuss the indirectness of much of Spanish writing. 5. Tebeaux (p. 54) and Montaño-Harmon (p. 418) explain that Spanish writers reject abrupt starts to their texts preferring to lead the reader through an introductory or anticipatory stage before signaling the topic. These are the findings studied in the e-mail memo research.

\subsection{U.S. e-mail research}

In addition to the styles and moves predicted to appear in Mexican business writing discussed above, this study also investigated what might be called the formatting of Mexican business e-mails. No studies of Mexican e-mail formatting are available; therefore, there is no basic description against which to compare this study's findings. Instead, this study compared Mexican e-mail formatting to that of U.S. business e-mail formatting for contrastive purposes.

Research into private computer mediated communication (CMC) tend to deal with concerns such as privacy issues (CAPPEL, 1993; 
SHIEH, 1994); flaming (GOODE; JOHNSON); (AMIRREZVANI, 1993), and comparing e-mail to oral and traditional written communication forms (HAWISHER, 1998) (MORAN; HAWISHER, 1998). One glaring exception is the work of JoAnne Yates and Wanda Orlikowski.

Yates and Orlikowski (1992) trace the development of office memos through electronic versions. While e-mail is clearly patterned after memo format (To: From: Subject: headings), it has some characteristics distinct from paper memos because of the requirements of early e-mail software. For example, in early software the To and From fields contained programming code and not English. They speculate that this may have led to the practice of using salutations and closings (Dear Adda and Regards, Mary respectively) in e-mail memos which differs from common practice in paper memos. Some researchers judge these differences to be aberrant genre choices to be avoided (MACKIEWICZ, 2003), but Yates and Orlikowski propose that these practices are "modifying existing genre rules in ways that may ultimately lead to the emergence of new genres in response to new recurrent situations" (p. $317)$.

\section{METHODS}

This section describes the data collection and analysis processes of this study. The goal of the research is to begin a generic description of Mexican business e-mails. To do so, 285 e-mail messages were collected from three Mexican resort (MP) managers over a course of 12 weeks. The three groups of messages, one group each from authors in upper-, middle-, and lower-management, were commingled and arranged in alphabetical order by subject line. From this grouping, every fifth message was selected for analysis. Counting the embedded messages within each e-mail, a total of 107 messages were analyzed.

\subsection{The e-mail contributors}

Like any resort or hotel, MP employs a significant number of employees who do not have office jobs. The majority of these workers never use computers, much less e-mail in the course of the workday. 
Those employees who do use computers and e-mail are typically in management holding ranks that range from supervisor to district manager.

Even though the messages were collected from just three people, they represent the writing practices of a much larger number of authors. Embedded messages serve to significantly increase the number of messages studied and they also contribute to the diversity of author styles and choices investigated. Two of the managers contributed many more messages written by other people compared to the number of messages contributed that they themselves had written. The actual number of authors represented is approximately thirty-five the vast majority of whom meet the same general qualifications of my initial description-Mexican professionals, college educated in Mexico and working in Mexico.

The first writer/contributor, A, was the resident manager of the entire hotel complex (at that time two hotels, currently three hotels) in Nuevo Vallarta. He was responsible for overall management of the existing hotels and was heavily involved in overseeing the construction and development of the newest hotel for the resort at this site.

The second writer/contributor, $\mathrm{N}$, was the front-desk manager of a 200-room hotel in the group. He was responsible for the smooth running of the check-in and check-out process and for overseeing all front-desk personnel in that hotel.

The final writer/contributor, G, was the head of Training and Development in the Human Resources department of the resort. She coordinated all training, induction and developmental programs for all employees.

Each of these people was college educated with the equivalent of bachelor's degrees from Mexican universities. None of them studied or worked in the U.S. but they had traveled in the US and G had lived in Canada for a short period many years earlier.

\subsection{The issues studied}

In addition to demographic data such as author's gender, internal or external origin of message, and the purpose of the message (request 
information, inform the recipient of something, or direct the recipient to do something), the analysis gauged whether the messages meet the descriptive issues statements formed based on the literature. These issues are that Mexican e-mail messages:

1. are non-linear using additive methods of organization (MONTAÑO-HARMON, 1991; TEBEAUX, 1999; and THATCHER, 1998 and 1999)

2. provide large amounts of specific detail (THATCHER, 1999; MARTÍN, 2003)

3. are indirect (THATCHER, 1998 AND 1999; TEBEAUX, 1999; MARTÍN, 2003; MORENO, 2004)

4. contain "ornate and flowery" language (MONTAÑOHARMON, 1991; REPPEN; GRABE, 1993)

5. address personal concerns before broaching business purposes (TEBEAUX, 1999; MONTAÑO- HARMON, 1991)

6. do not use greetings (ORLIKOWSKI; YATES, 1994; MACKIEWICZ, 2003; HOROWITZ; BARCHILON, 1994)

7. do not contain (typed) signatures (ORLIKOWSKI; YATES, 1994; MACKIEWICZ, 2003; HOROWITZ; BARCHILON, 1994)

8. are not written in all uppercase letters (MACKIEWICZ, 2003)

\subsection{Data collection}

Issues one through four were studied using a rhetorical analysis and the remaining issues were simple presence/absence count items. The rhetorical text analysis is a form of discourse analysis. This approach employs a Grounded Theory framework (STRAUSS; CORBIN, 1994). The corpus of messages was analyzed to determine whether the messages had the characteristics described in the previous research into Spanish-language writing.

The rhetorical analysis called for multiple close readings examining the e-mail messages for characteristics defined, exemplified, and explained in heuristics developed for this purpose based on the literature. Each message was read closely and coded a minimum of five times concentrating on one issue characteristic at a time. The repeated 
readings refined the genre description and clarified the information in the literature which is an expected attribute of qualitative research (NEUMAN, 2000), and it closely follows the procedures outlined in Orlikowski and Yates.

Descriptive data were also collected. Please see Table 2 below for this information.

Table 2 - Categorization of the Messages

\begin{tabular}{ll|lll|l|lll}
\hline Origin & & \multicolumn{3}{|c|}{ Power level compared to author } & \multicolumn{3}{c}{ Purpose } \\
\hline Internal & External & Above & Below & Lateral & All dir. & Request & Report & Directive \\
$92.5 \%$ & $7.5 \%$ & $28 \%$ & $41 \%$ & $15 \%$ & $5.6 \% *$ & $23.4 \%$ & $42.1 \%$ & $34.6 \%$ \\
\hline
\end{tabular}

*Audience percentages do not total $100 \%$ because of omission of $9.3 \%$ of messages where power direction was not applicable, for example, messages from resort customers.

\section{RESULTS}

This section contains a description of the results of the e-mail study. First, the rhetorical analysis is presented and includes examples from the corpus. Then, the count analysis is presented.

\subsection{Rhetorical analysis results}

Issue statement one predicts that Mexican e-mail message paragraphs will predominantly progress using non-linear organization. Paragraphs will be marked by roundabout topic development (MONTAÑO-HARMON, 1991, p. 418), or by topics that progress in several directions at once or text chunks that discuss several topics (TEBEAUX, 1999, p. 57), or to organization by addition or accumulation (THATCHER, 1998, p. 373).

Only $17.7 \%$ of the messages studied were non-linear. All of the non-linear messages were deemed so because of their use of additive organization; none of them had roundabout topic development, multiple topics or topics that progress in several directions. This means that $82.3 \%$ are linear in construction showing a rather strong preference for linearly organized e-mail memos, i.e., the literature is incorrect. 
Below are two sample messages deemed non-linear. The messages are reproduced verbatim meaning that all aspects of the message are copied here, including the use of upper or lower case letters and the presence/absence of punctuation including diacritic marks. The author performed all translations.

Example 1

A. (name), IMPORTANTE QUE DE FORMA PERIODICA VISITES AL C.P. C. (name) CON TODOS TUS PENDIENTES DE AMA DE LLAVES DEL DESARROLLO ESPECIALMENTE LO RELACIONADO A COMPRAS Y AUTORIZACIONES, ESTABLESCAS PRIORIDADES DE COMPRA PARA TODO EL DESARROLLO [names the three hotels ], ESA ES UNA DE TUS FUNCIONES PRINCIPALES.

A. (name), IT'S IMPORTANT THAT YOU PERIODICALLY VISIT CPA C. (name) WITH ALL OF YOUR PENDINGS (ORDERS AND PURCHASES) FOR HOUSEKEEPING FOR THE ENTIRE DEVELOPMENT ESPECIALLY THOSE RELATED TO PURCHASES AND AUTHORIZATIONS, ESTABLISH PURCHASE PRIORITIES FOR THE WHOLE DEVELOPMENT [names the three hotels], IT IS ONE OF YOUR PRINCIPAL FUNCTIONS.

Example 2

Sr. A (name) : Aproximadamente a las 3:00 am se presento en las casseta de Seguridad la Srta X encargada de Boutique en estado de ebriedad pidiendole a seguridad que la comunicaran por telefono a su habitacion, lo cual negue el permiso.

Mr. A (name) : At approximately 3:00 am Miss X in charge of the Boutique appeared at the Security hut in a state of inebriation asking security to put her in touch with you in your dwelling by phone permission which I denied.

Example 1 shows a chunk of text that covers at least three topics: 1) A. is told to take her pending paperwork to the controller periodically for review; 2) A. is reminded she is responsible for housekeeping supplies/purchases for the entire complex; and 3) A. is told to set up 
purchase priorities for the whole complex because it is one of her principal functions. The three topics are separated by commas only and display accumulative organization. The paragraph is not organized by first claiming a major topic and then following up with supporting statements; instead it addresses three topics by simply listing them. The message does not state the main idea (A. has to develop a system for tracking orders and keeping on top of the supplies needed by housekeeping) and then follow this statement with support or explanation.

Example 2 is a message with at least four topics contained in one long sentence: 1) Miss $\mathrm{X}$ who runs the boutique appeared at the security hut at 3 a.m., 2) Miss X was drunk, 3) Miss X wanted security personnel to call the manager in his residence, and 4) the security officer refused. Again, accumulative organization operates here.

Issue statement two says that Mexican e-mails will provide large amounts of specific detail. For purposes of this study, specific and detailed refers to the preference for naming the particular and citing the concrete "down to the penny" detail. Twelve messages fit this category $(11 \%)$. Eighty percent of the "specific" messages were directed down the power scale and for the purposes of giving an order (50\%), requesting information $(25 \%)$, or providing information $(25 \%)$. The fact that the purpose was usually to give an order from a superior to a subordinate may make the specificity of these messages a little surprising unless one is cognizant of the cultural preference for patriarchal management styles in Mexico. It may seem out of character for a manager to go into such detail in directing a subordinate's actions, but not in Mexico. According to Kras "[i]n Mexico there is no tradition of delegation of authority [...] (KRAS, 1995, p. 45). The boss is an extension of the autocratic, authoritarian father image. As a result, delegation of responsibility normally takes the form of assignment of specific tasks.

With only $11 \%$ of the corpus deemed specific and detailed, the remaining $89 \%$ are not as focused on specifics and details. This means another issue statement concerning Mexican business communications is not supported and that the literature is incorrect.

Here are two sample messages judged specific and detailed. 
Example 3

Estimados X y Z (a person from accounting and a front desk manager),

Adjunto archivo con desgloce de Golf del Grupo Golden Gate con estancia del $1^{\circ}$ al 8 de Marzo, ellos Jugaran solamente 3 dias de los 5 dias contemplados en el Paquete.

1) Z, asegurar el cargo de US $\$ 13.00$ por Jugador por Dia por concepto de Carrito y Caddie.

2) X, la diferencia sobrante del Credito en Golf Ingresarla a Cuartos.

3) $Z$, $X$ y CP C, se deberan elaborar 3 vales de caja para hacerlos efectivo los dias 3, 5 y 6 de Marzo que son los dias de Juego para cubrir $\$ 150.00$ pesos por cada Caddie, Cada Caddie a su vez atendera a 4 Jugadores al mismo tiempo. Por lo que seran un maximo de 12 Caddies $X \$ 150.00=\$ 1,800.00$ Pesos por Cada Dia de Juego, esto se debe pagar Cash al final de la ronda directamente a los Caddies; Mayan Country Club no nos puede facturar este concepto.

Z, Hacer formato en forma de Lista con 12 Lineas para nombre y firma y poder recabar nombre y firma de cada Caddie al momento de hacerles el pago, y tener soporte y control del total pagado.

$\mathrm{X}$, indicarnos si se aplica algun movimiento en la cuenta maestra del grupo reflejando el pago de los caddies.

$\mathrm{X}$, tomar nota que los Caddies y Carro de Golf se cubren con la diferencia a favor No ejercida por el Grupo al Jugar solo 3 dias en vez de 5 .

Sr. B (controller), se te presentaran los vales para firma.

En caso de dudas favor de contactarme.

Esteemed $\mathrm{X}$ and Z,

I'm attaching a file with an itemization of the Golden Gate Golf Group staying the first through the eighth of March, they'll Play only three days out of the five they had planned in the Packet. 
1) Z, verify the $\$ 13$ (US) charge per Player per Day for the Cart and Caddie.

2) $X$, Invest the Credit overage in Golf to Rooms.

3) $\mathrm{Z}, \mathrm{X}$ and $\mathrm{CPA} B$, you will need to fill out three vouchers in order to make them effective the third, fifth and sixth of March which are the days (they're) Playing in order to cover the $\$ 150$ pesos for each Caddie, Each Caddie in turn will attend 4 Players at the same time. This results in a maximum of 12 Caddies times $\$ 150=\$ 1,800$ Pesos for Each Day of Play, this should be paid in Cash directly to the Caddies at the end of the round; Mayan Country Club can't bill us for this.

$\mathrm{Z}$, Make a form that is a List with 12 Lines for the name and signature and be sure to get the name and signature of each Caddie when you pay them, and have a clipboard and control over the total paid.

$\mathrm{X}$, let us know if some movement in the master account applies reflecting the caddies' payment.

$\mathrm{X}$, take note that the Caddies and Golf Cart will be covered with the positive difference from the Group's Not electing to Play except 3 days instead of 5 .

Mr. B, the vouchers will be presented to you for signing.

If you have questions (doubts) please contact me.

In Example 3, the General Manager of the entire complex explained to a lower-level manager how to record and document the act of paying caddies for a group's golf outings. This directive included information such as the amount to pay the caddies, and very detailed and specific information such as the suggestion to draw lines on a sheet of paper for the caddies' signatures as they received their pay and the instruction to have a clipboard available to facilitate collecting the signatures. 
Example 4

ESTIMADO A,

FAVOR DE PONER INFORMACION DE HORA DE LLEGADA DE LOS ESTUDIANTES EN RESERVACIONES.

M, FAVOR DE PROGRAMAR TRANSPORTACION CON SR. C. HACER LETRERO QUE DIGA: 'BIENVENIDOS! MP NUEVO VALLARTA INTERNSHIP 2004'

$\mathrm{X}$, FAVOR DE RECIBRLOS PERSONALMENTE Y ACLARAR LAS DUDAS QUE PEUDAN TENER.

Y, COLOCAR BANDA 'MP'.

VER PESTAÑA DE ITINERARIOS EN ARCHIVO ADJUNTO.

SALUDOS,

ESTEEMED A,

PLEASE PUT INFORMATION ON THE STUDENTS' HOUR OF ARRIVAL IN RESERVATIONS.

M, PLEASE ARRANGE TRANSPORTATION WITH MR C. MAKE A SIGN THAT SAYS: 'WELCOME! MP NUEVO VALLARTA INTERNSHIP 2004'

$\mathrm{X}$, PLEASE RECEIVE THEM PERSONALLY AND CLEAR UP THE QUESTIONS (DOUBTS) THAT THEY MIGHT HAVE.

Y, PLACE AN 'MP' BAND (ON THEM.)

SEE THE ITINERARIES TAB IN THE ATTACHED FILE.

SALUTATIONS,

Again, Example 4 is from a very high level manager. He gives detailed directions to four different employees down to the specific wording for the sign that the driver was to hold while waiting for the interns at the airport. These four message recipients occupy levels in the 
power hierarchy ranging from one step below the high level manager (the sender) to several steps below the sender.

Issue statement four states that Mexican e-mail messages contain "ornate and flowery "choices in vocabulary. For the purpose of this study, "ornate and flowery" is defined as language that does not reflect everyday vocabulary choices or that is used to achieve a tone of either formality or subservience. None of the literature reviewed above contains a definition of "ornate and flowery" language.

Only three of the $107(2.8 \%)$ messages analyzed contained what could be considered "flowery or ornate" language. Two of these were invitations and one message was between close friends who both work at MP. One example of "ornate and flowery" language appears in example 5.

\section{Example 5}

Estimados Colegas,

Estan cordialmente invitados a hacer presencia a las 6:00 p. m. 6:30 p. m. a un Coctel de Bienvenida a los profesores que participan en la Conferencia Academica del Programa Internship, este coctel es Hoy Jueves 8 de Julio.

Es importante su presencia pues se les presentara como los Ejecutivos de Area y Supervisores de los Estudiantes del programa de Internship.

Gracias,

Esteemed Colleagues,

You are cordially invited to make an appearance at 6:00 p. m. 6:30 p. m. at a Welcome Cocktail [party] for the professors who participate in the Academic Conference of the Internship Program, this cocktail [party] is Today, Thursday July 8th.

Your presence is important since you will be introduced as the Area Executives and Supervisors of the Students in the Internship program.

Thanks, 
Invitations make-up a genre that appears to require formal and cordial vocabulary regardless of the language they are written in. The fact that the invitations are extended at work does not appear to nullify the expectation for formality.

Based on the proposition that Mexican educational institutions teach students to use a wide array of vocabulary choices, it would intuitively make sense to suppose that learners' writing practices would be affected by this throughout their writing careers. Montaño-Harmon's investigation of Mexican writing textbooks and my own review of two Spanish writing textbooks (MORALES, Curso Basico de redaccion: de la oracion al parrafo, 1991) (MORALES, 1995) indicate that this is indeed one of the goals of writing instruction; writers are encouraged to be careful with vocabulary choices and to explore different ways of expressing ideas through the use of synonyms and antonyms. Obviously, using an extensive vocabulary does not necessarily lead to "ornate and flowery" language, but it seems to hint at the possibility. Another issue statement from the literature found to be incorrect.

\subsection{Count analysis results}

Issue statements five through eight describe characteristics that are easily analyzed as either present or not. They are-(5) mentioning personal issues before getting to business, (6) use of salutation, (7) use of typed signatures and, (8) use of all uppercase font face. Table 3 below provides the percentages of e-mails that contain these characteristics.

Table 3 - Issue statements 5 through 8

\begin{tabular}{llll}
\hline Issue 5 & Issue 6 & Issue 7 & Issue 8 \\
\hline Personal first & No Salutation & No Signature & Not Uppercase \\
$7.5 \%$ & $28 \%$ & $22.4 \%$ & $58 \%$ \\
\hline
\end{tabular}

Contrary to the literature describing Spanish writing, this study finds that, in general, Mexican e-mail memos are organized linearly, are not highly specific with a high level of detail, are direct in approaching the main topic, do not contain "ornate and flowery" language, do not address personal issues before work-related issues, do contain 
salutations, do contain signature blocks, but they do not contain all uppercase font faces. Of the eight issue statements investigated (listed in "Issues studied" above), only item 8 was confirmed as a correct description of the messages in this corpus. The majority of messages are not written in all uppercase fontface. None of the other issues was found to be correct regarding this corpus.

\section{DISCUSSION}

Why would the e-mail messages studied contain so few of the characteristics described in the literature as being typical of Spanish language written business communication?

One answer to this question may relate to the fact that this written communication is e-mail, a medium that is still not fully described or understood by scholars in any language regardless of the purposes of the messages studied. All of the Spanish-language studies discussed above investigated paper documents so the difference in medium is a major distinction between this and previous studies. The hybrid nature of email (partly phone or conversation-like and partly written memo or notelike) makes it very difficult to make generalized claims about e-mail memorandum characteristics. And, one needs to be careful to not confuse medium with genre.

In defining media, Yates and Orlikowski cautioned against confusing medium with genre (YATES; ORLIKOWSKI, 1992, p. 310). They noted that genres may be "physically created, transmitted, and stored in various media. Thus, comparing memos with electronic mail, for example, confounds the concept of communication medium with that of communication genre" (p. 311). The e-mail study described here investigates the genre of memos in the medium of e-mail. The messages are considered to be memos not because of their appearance (memo layout) but because of their purposes.

Many e-mail programs lay out messages in modified memo format but that may simply be a holdover from earlier iterations that contained routing and delivery information at the head of the message. Electronic mail messages could be formatted in other ways, they just happen to look like memos today: like other computer interfaces, this design 
feature could change too. The point is that the messages studied are memos because of their purposes.

The messages studied had the overriding purpose of conducting the day-to-day business of the resort; a purpose that is quite different from documenting transactions or serving archival functions or promoting goodwill with external customers-some of the purposes of the written documents in previous studies. The fact that the e-mail messages were functional communications may at least partially answer why none of the first five issues were true for these messages; they were overwhelmingly linear and direct with "normal" vocabulary choices, an expected level of specificity for the culture and expected fronting of the topic at hand.

Another possible explanation for these findings may be that this specific industry or this specific site employs practices outside of the norm for Spanish language business writing. Perhaps having U.S. and Canadian English speakers as primary customers has so heavily influenced business practices in the resort/hospitality industry or this individual resort that even the business writing practices have been influenced.

At least for the MP resort, common practice indicates that writers ought to include personal greetings in e-mail messages. Considering the cultural value placed on the personal in Mexico, this finding is not surprising. In Mexican e-mail it is common practice to begin an e-mail with the recipient's name. This fact has educational implications because it is inappropriate to refer to many people by their first names in Spanish; titles are required instead. Students of Spanish as a second language would need to be careful with this practice in order to avoid offending Mexican e-mail recipients by neglecting to use appropriate titles.

Only $22.4 \%$ of the messages analyzed relied on the memo formatting "from" line to identify the author. Surprisingly, $24.3 \%$ of the messages contained a typed signature without a programmed signature block. The one remaining message had both a signature block and a typed signature. So, unlike the suggestions made for drafting e-mails in the U.S., Mexican e-mails (at this resort) usually (77.6\% of incidences) 
included some kind of signature apart from the "from" line of the e-mail program.

Thirty percent of the messages do use all capital letters and $12 \%$ of them contain excessive capitalization based on standard rules of capitalization in Spanish. The fact that almost one-third of the corpus was written all in capital letters is surprising.

However, it is not believed that the complete capitalization of messages is related to what in e-mail writing is known as flaming, although a couple of the all capitalized letters messages did appear to employ the upper case letters for emphasis based on the urgency or importance of the content. The simple explanation may be that the keyboard simply had the caps lock key engaged and the authors were not concerned by it.

In conclusion, this study makes it abundantly clear that much more research into LOTE writing genres needs to take place. Results of academic writing studies do not carry over to workplace genres. If a worthy goal of higher education is to improve intercultural written communication, then accurate information about common genres of contact, such as e-mail, must be studied and described in detail.

\section{REFERENCES}

AMIRREZVANI, A. Tips for taming e-mail. PC World, v. 11, n. 11, p. 285-295, 1993.

ANDERSON, P. V. Technical communication: a reader-centered approach. 6th ed. Boston: Thomson Higher Education, 2007.

BURNETT, R. E. Technical communication. Belmont: Wadsworth, 2006.

CAPPEL, J.J. Closing the e-mail privacy gap. Journal of Systems

Management, v. 44, n. 12, p. 6-11, 1993.

CIBER. Web site for the CIBER centers. 2004. Available at

$<$ http://ciber.centers.purdue.edu>. Accessed Oct. 2004.

CONNOR, U. Intercultural rhetoric research; Beyond texts. English for Academic Purposes, p. 291-304, 2004.

GOODE, J.; JOHNSON, M. Putting out the flames: The etiquette and law of email. Online, v. 15, n. 6, p. 61-65. 
HAWISHER, G.; SELFE, C. Reflections on computers and composition studies at the century's end. In: SNYDER, I. (Ed.). Page to screen. New York: Routledge, 1998.

HOROWITZ, R.; BARCHILON, M. Stylistic guidelines for e-mail. IEEE Transactions on Professional Communication, v. 37, n. 4, p. 207-212, 1994.

HYON, S.; RONG, C.. Beyond the research article: University faculty genres and EAP graduate preparation. English for Specific Purposes, v. 23, n. 3, p. 233-263, 2004.

KAPLAN, R. B. A further note on contrastive rhetoric. Communication Quarterly, v. 24, n. 2, p. 12-19, 1976.

KRAS, E. Management in two cultures: bridging the gap between U.S. and Mexican managers. Yarmouth, Maine: Intercultural, 1995.

LANNON, J. M. Technical communication. New York: Longman, 2003.

LUX, P. Discourse styles of Anglo and Latin American college student writers. Unpublished dissertation. Arizona State University, 1991.

MACKIEWICZ, J. Which rules for online writing are worth following? A study of eight rules in eleven handbooks. IEEE Transactions on Professional Communication, v. 46, n. 2, p. 129-137, 2003.

MARTIN, p. M. A genre analysis of English and Spanish research paper abstracts in experimental Social Sciences. English for Specific Purposes, v. 22, n. 1, p. 25-44, 2003.

MAURIAL, A. The teaching of business communication in Peru. In: ULJIN, D.M. (Ed.). Intercultural discourse in business and technology. Berlin: Mouton de Gruyter, 1995. p. 141-149.

MONTAÑO-HARMON, M. R. Discourse features of written Mexican Spanish: Current research in contrastive rhetoric and its implications. Hispania, p. 417425, 1991.

MORALES, J. L. O. Curso basico de redaccion: de la oracion al parrafo. Madrid: Editorial Verbum, 1991.

Curso superior de redaccion. Coleccion Cervantes. Madrid: Editorial Verbum, 1995.

MORAN, C.; HAWISHER, G.. The rhetorics and languages of electronic mail. In: SNYDER, I. (Ed.). Page to screen. Routledge, 1998. p. 80-101. 
MORENO, A. Retrospective labeling in premise-conclusion metatext: An English-Spanish contrastive study of research articles on business and economics. Journal of English for Academic Purposes, v. 3, n. 4, p. 321-340, 2004.

NEUMAN, W. L. Social research methods: qualitative and quantitative approaches. Boston: Allyn and Bacon, 2000.

ORLIKOWSKI, W.; YATES. J.A. Genre repertoire: The structuring of communicative practices in organizations. Adminstrative Science Quarterly, v. 39, n. 4, p. 541-574, 1994.

ORTIZ, L. A. Cruzando la frontera de la comunicacion profesional entre Mexico y los Estados Unidos. Journal of Business Communication, v. 42, n. 1, p. 28-50, 2005.

REICHELT, M. Toward a more comprehensive view of L2 writing: Foreign language writing in the U.S. Journal of Second Language Writing, p. 181-204, 1999.

. A critical review of foreign language writing research on pedagogical approaches. Modern Language Journal, v. 85, n. iv, p. 579-598, 2001.

REID, J. Quantitative differences in English prose written by Arabic, Chinese, Spanish and English students. Colorado State University unpublished dissertation. 1988.

REPPEN, R; GRABE, W. Spanish transfer effects in the English writing of elementary school students. Lenguas Modernas, v. 20, p. 113-128, 1993.

SANTANA-SEDA, O. A contrastive study in rhetoric: A comparison of the organization of paragraphs as written by speakers of each language.

Unpublished dissertation. New York: 1974

SANTIAGO, R. L. A contrastive study of some rhetorical aspects in the writing of Spanish and English of Spanish-speaking college students in Puerto Rico. Unpublished dissertation Columbia University. New York: 1970.

SHIEH, J.; BALLARD, R.A.-L. E-mail privacy. Educom Review, p. 59-61, 1994.

SIMPSON, J. Topical structure analysis of academic paragraphs in English and Spanish. Journal of Second Language Writing, v. 9, n. 3, p. 293-309, 2000.

SPANISH LANGUAGE. Encyclopedia Britannica On-Line. 2009. Available at EBSCO. Accessed April 30, 2009. 
STRAUSS, A.; CORBIN, J. Grounding theory methodology: an overview. In: DENZIN, N.; LINCOLN, Y. (Eds.). Handbook of qualitative research. Thousand Oaks: Sage, 1994. p. 273-285.

STREI, G. J. A contrastive study of the structure of rhetoric in English and Spanish composition. Unpublished dissertation McGill University. Montreal: 1972.

SWALES, J. M. Genre analysis: English in academic and research settings. Cambridge: Cambridge University Press, 1990.

TEBEAUX, E. Designing written business communication along the shifting cultural contiuum: The new face of Mexico. Journal of Business and Technical Communication, p. 49-85, 1999.

THATCHER, B. L. Writing policies and procedures in a U.S./South American context. Technical Communication Quarterly, p. 365-399, 1998.

Cultural and rhetorical adaptations for South American audiences.

Technical Communication, v. 46, n. 2, p. 177-195, 1999).

VALDES, G.; ECHEVARRIARZA, M.P.; HARO, P. The development of writing abilities in a foreign language: Contributions toward a general theory of L2 writing. The Modern Language Journal, v. 76, n. iii, p. 333-352, 1992.

YATES, J.A.; ORLIKOWSKI, W.. Genres of organization communication: A structurational approach to studying communication and media. The Academy of Management Review, v. 17, n. 2, p. 299-327, 1992.

Recebido em 30/08/2010. Aprovado em 08/12/2010.

Título: Definindo o gênero e-mail de negócios mexicano

Autor: Therese Judge

Resumo: Com base nas congruências entre os achados de pesquisas sobre a escrita em lingua espanhola e aqueles encontrados em pesquisas sobre a escrita de email em inglês americano, este estudo investiga emails mexicanos. Os achados da literatura são formulados como declarações de questão com o propósito de confirmar ou rejeitar sua aplicabilidade aos emails mexicanos selecionados. $O$ estudo emprega tanto a análise retórica qualitativa, quanto a análise de cunho quantitativo da presença/ausência.Das oito declarações de questão previstas para descrever os e-mails de negócios mexicanos pela literatura, apenas uma foi afirmada - significando que a informação atualmente disponivel sobre emails mexicanos em local de trabalbo está incorreta e/ ou incompleta.

Palavras-chave: Gênero. Intercultural. Email. Espanhol. 
Titulo: Definiendo el género correo electrónico de negocios mexicano Autor: Therese Judge

Resumen: Con base en las congruencias entre los resultados de las investigaciones sobre la escritura en la lengua española y aquellos encontrados en las investigaciones sobre la escritura en correo electrónico en inglés de los EE.UU., este estudio investiga correos electrónicos mexicanos. Los resultados de la literatura son formulados como declaraciones de cuestión con el propósito de confirmar o rechazar su aplicabilidad a los correos electrónicos mexicanos seleccionados. El estudio emplea tanto el análisis retórico cualitativo, como el análisis de aspecto cuantitativo de presencia/ausencia.De las ocho declaraciones de cuestión previstas para describir los correos electrónicos de negocios mexicanos por la literatura, apenas una fue afirmada - significando que la información actualmente disponible sobre los correos electrónicos mexicanos en el local de trabajo está incorrecta y/ o incompleta.

Palabras-clave: Género. Intercultural. Correo electrónico. Español.

JUDGE - Defining the genre... 